\title{
The Problem of Dates in Bibliographic Citations
}

In the bibliographic citation, date is important for two reasons: it helps to identify a particular physical book or other item; and gives an indication of the time of the item's content or thought. For many bibliographic entries, the two purposes cannot be satisfied by one date. Examples are given to show that specification of date is often inadequate in bibliographies and library catalogs. Suggestions for improvement are offered, based largely on contributions of analytic bibliographers.

B EYOND QUeSTION, a satisfactory bibliographic entry gives the date of publication. Because the inclusion of such a date has become virtually automatic, it may be well to review first the reasons for it.

\section{The Two Principal Uses of Bibliographic Dates}

For one thing, the date may be necessary to identify the physical book, placing it as a copy of a certain impression. The practical consequence here may be serious, for in the case of a scarce or rare item, the date may make a great difference in value-or at least price. This physical identification is recognized also as important for the scholar. Charles Evans was only slightly too extravagant when in his famous preface he declared, “. . . the fact first in importance in bibliographical research is the date-always the date!"1 A first printing should be distinguished from a second, even though the text be the same, and as Dunkin says, ". . . the only difference

1 Charles Evans, American Bibliography (Chicago: printed for the author, 1903-1959), I, xi.

Mr. Broadus is Professor of Library Science, Northern Illinois University, DeKalb, Illinois. between one issue and another-or at least the difference most easily shownis in the imprint."2

To the common reader, the bibliographic date may be helpful in identifying more precisely a particular edition of a work-an edition which may be needed to find the page number of a passage cited in the bibliographic reference. Take, as an example, an article with a footnote citation to "A. N. Whitehead, Science and the Modern World, The New American Library Edition, 1958 , p. 178." In order to find the quoted passage one must use the reprint, which has a total of 191 pages; if he goes to the original edition, published in 1925, he looks in vain for the page given in the footnote, for that original had 296 pages. Therefore, he is not satisfied to obtain another text with the same words as those used by the citing author; he needs a text with the same paging; otherwise he spends considerable time in trying to find the passage referred to. The date of publication helps to identify the "correct" reprint, and the catalog (especially in a university library) should clearly indicate that date.

\footnotetext{
2 Paul S. Dunkin, How to Catalog a Rare Book (Chicago: ALA, 1951), p. 28
} 
This example will serve also to introduce the second principal use of bibliographic dates. It is not enough to be able to identify a printing of the physical book. If one thinks Whitehead's statement was made first in 1958, he is misled, for he interprets the quotation apart from its 1925 context, and its meaning becomes quite different. ${ }^{3}$ To prevent this eventuality, the bibliographic reference ought to do something else: indicate as accurately as possible the effective date of the material in the source cited.

This purpose has not been overlooked entirely by library catalogers. The Library of Congress Rules for Descriptive Cataloging, in referring to imprint, said, "The date generally indicates the timeliness of the subject matter." 4 This need for a date which has to do with content is one reason why many catalogers use the copyright date as well as-or even in preference to-the imprint date. Piercy was concise: "If no copyright date is shown, the imprint (title page) date is used." "5 Akers expressed the reason simply:

The important point is not when the book was printed, but when it was written and when the latest changes in it were made. The latest copyright date shows this, for books can be recopyrighted only when important changes are made in them; therefore, the latest copyright date is used. . . . If there is no copyright date, give the date

\footnotetext{
3 Jorge Luis Borges, in a story written in 1939 ("Pierre Menard, author of Don Quixote," translated by Anthony Bonner, in his Ficciones, ed. Anthony Kerrigan (New York: Grove Press, 1962), p. 45-55) imagines part of Cervantes' novel to have been written word for word by a twentieth century author, and shows how the interpretation of certain passages would have to be changed.

${ }^{4}$ U.S. Library of Congress, Descriptive Cataloging Division. Rules for Descriptive Cataloging in the Library of Congress (Washington: U.S. Government Printing Office, 1949), p. 16.

5 Esther J. Piercy, Commonsense Cataloging (New York: H. W. Wilson Company, 1965), p. 53. See also: A. Stan Rescoe, Cataloging Made Easy (3rd ed.; New York: Scarecrow Press, 1962), p. 96; Bohdan S. Wynar, Introduction to Cataloging and Classification; A Teaching Guide . . . (2nd ed., rev. and enlarged; Denver: Colorado Bibliographic Institute, 1966), p. 47.
}

of publication; i.e., the date at the foot of the title page....6

The assumption here is that the date of printing is less important than the approximate date of thought-that identifying the specific physical book is not so crucial as placing the time of the content. Esdaile states it this way:

Intelligent readers demand dates on books, and preferably in the traditional and conspicuous position at the foot of the titlepage. They also demand a statement of the date of the first edition of the book itself, and of the present recension of it. It is vital to them to know whether the author wrote, or revised what he had written, before or after certain events or publications. In most branches of natural science, knowledge advances and theory changes with such rapidity that a book five years old or less is out of date and if undated is a fraud. ${ }^{7}$

William Warner Bishop put the matter strongly also, in his Practical Handook: "In nine cases out of ten when a book other than fiction is looked up in a card catalog, the place and date determine the reader's selection of a book by an author previously unknown to him."8 This same concern about the significance of date is indicated by those bibliographies (found more often in science than in other disciplines) which place the year as the first element in the citation.

Though most manuals and guides for writers are not very precise on the matter of dates, at least one recognizes their importance:

A well-made bibliography ... presents the following information:

(6) The date of publication (the date on

6 Susan Grey Akers, Simple Library Cataloging (4th ed.; Chicago: ALA, 1954), p. 85.

7 Arundell Esdaile, A Student's Manual of Bibliography, Revised by Roy Stokes (3rd ed.; London: George Allen \& Unwin Ltd. and The [British] Library Association, 1954 ), p. 96.

${ }^{8}$ William Warner Bishop, Practical Handbook of Modern Library Cataloging (Baltimore: Williams \& Wilkins, 1914), p. 92. 
the copyright page, not the one on the title page, which is changed with every printing).$^{9}$

In some of the less conventional systems for information retrieval, dates are given considerable importance. They are included in two of the roles in the coordinate indexing plan developed by the Battelle Memorial Institute for the Engineers' Joint Council. Role 9 provides for a date (which may include month as well as year) used to specify the time in which the operation described in the document took place. Role 0 is primarily for bibliographic information, including dates of publication. It would seem that the most important function of date in this latter role is to give the time of the discussion of the operation, or the time of the document's content rather than of the physical document per se. This date can be used in coordination to obtain, say, materials representing the thought of 1959 on the subject of uranium isotopes. ${ }^{10}$

In a way both purposes-identification of the physical book or document, and indication of the time of its content -are served by Blanck in the great Bibliography of American Literature, when he goes to such great lengths to establish the publication date of an entry. ${ }^{11}$ The Library of Congress would seem to serve both purposes also in the unusual care

\footnotetext{
${ }^{9}$ Words into Type; a Guide in the Preparation of Manuscripts; (new rev. ed.; New York: AppletonCentury-Crofts, 1964), p. 33.

${ }^{10}$ See John C. Costello, Coordinate Indexing (New Brunswick: Graduate School of Library Service, Rutgers-The State University, 1966), p. 106, 107; also Battelle Memorial Institute, The Engineers Joint Council System of Roles: ... (Columbus: Battelle, 1964 ?). The coordinate index itself has no need for a date to identify the physical document; that is placed, typically, by serial number, and may have a complete bibliographic entry in a separate file. However, the makers of the indexing system are not entirely clear on the purposes of dates as coordinating aspects. Probably this lack of precision is due to the fact that the main problem discussed in the present paper has not (yet) made trouble in the literature of engineering.

${ }^{11} \mathrm{Jacob}$ N. Blanck, Bibliography of American Literature (New Haven: Yale University Press, 1955-63), I, p. xxxvi.
}

which it bestows on some items. For example the small book Are Liberal Arts Colleges Becoming Professional Schools? by Columbia University, Teachers College, Institute of Higher Education, is given the date, "1958 i.e. 1959, "1958]."

\section{A Specific Instance of the Problem}

That we need some improvement in specifications for the bibliographic recording of dates is indicated by the following example chosen from several known ones. In 1962 the New York firm of Russell and Russell issued a reprint of William John Courthope's six-volume History of English Poetry, having photographed the original pages of the 18951910 edition. The reprint has only a few omissions, but one of these is the original date of publication. ${ }^{12}$ The Library of Congress catalog card number 61-13773 gives 1962 as the date of publication with no reference to the fact that it is a reprint of a text more than a half-century old.

Though this set was cataloged by the Library of Congress according to its Rules for Descriptive Cataloging ${ }^{13}$ before the publication of the New AngloAmerican Code, there is no reason to believe that use of the new code would have insured a better indication of the real date of the book's ideas. The new general rule for date (No. 141) is:

An imprint date on the title page of a work is always recorded. If this date is known to be incorrect, the correct date is added in brackets.

$$
1947 \text { [i.e. 1957] }{ }^{14}
$$

In the case of Courthope, 1962 is certainly not known to be an incorrect date

12 This omission of original date is not habitual with Russell and Russell, and in the Publisher's Trade List Annual of 1966 and following, the date for the Courthope set is given as "[1895-1906] 1962."

${ }^{13} \mathrm{Op}$. cit.

${ }^{14}$ Anglo-American Cataloging Rules; Prepared by the American Library Association, The Library of Congress, The Library Association, and The Canadian Library Association, North American Text (Chicago: ALA, 1967), p. 203. 
for the reprint (no typographical error is apparent); therefore only the date "1962" would appear in the entry. Rule 141 further recommends:

If only the original imprint date appears on the title page of a later impression or of a reprint edition, the date of the reprint is added.

\section{6 [reprinted 1965] ${ }^{15}$}

This part of the rule would not affect the Courthope set, because the original imprint date does not appear at all. The rule goes on:

If there is no imprint date on the title page, a date of publication or printing found in another part of the work or in a reference source is supplied. ${ }^{16}$

So, if there were no date on the title page of Courthope, catalogers would be supposed to find one and might be led to the one most useful from the standpoint of content. That procedure is precluded, however, by the "if" clause in the rule.

The cataloging profession is by no means the only group at fault; other bibliographers also miss the mark. Notice a couple of examples, each produced under sponsorship from which should be expected the best in bibliographic citation. Each gives for Courthope the 1962 date only: The Essay and General Literature Index volume for 1960-1964, ${ }^{17}$ and the new Books for College Libraries. ${ }^{18}$ The bibliographic information for the latter was obtained largely from Library of Congress cards, so the inadequate Courthope date is understandable if not quite forgivable. If such guides are used most heavily by the very people who do not know a field

${ }^{15}$ Ibid.

${ }^{16}$ Ibid., p. 204.

17 The Essay and General Literature Index, 1960-64 (New York: H. W. Wilson Company, 1965), p. 1543.

${ }_{18}$ Books for College Libraries . . . prepared under the direction of Melvin J. Voigt and Joseph H. Treyz (Chicago: ALA, 1967), p. 629. well, the need for better bibliographic dating is even greater.

\section{NeEd For Improved Rules AND Practice}

In truth, the user of any bibliography or library catalog simply deserves a better date for items like the Courthope History. Regrettably, most bibliographic manuals and guides for thesis writing, not recognizing its importance, are imprecise on this point (an exception, of course, is Words into Type noted previously). To quote only one of the more widely used guides: "If the date of publication does not appear on the titlepage, the copyright date from the following page may be substituted." 19

The authors of guides probably are wise, though. It may be too much to expect of the average writer that he take responsibility for the more difficult points in bibliography. Since no purpose would be served by threatening with destruction all those who compile bibliographies or make footnote citations, it may help to throw a few suggestions in the direction of catalogers and documentalists. If an item is dated satisfactorily in the library catalog, others citing the book should be able to use the same bibliographic information. (In any case, it would help the general reader.)

Charles A. Cutter set a good pace with his rule number 274 :

In cataloging reprints, Full cataloging should give the date of the original edition.

The labor of always hunting up the original date is so great that Medium cataloging may be allowed to give it when it can easily be ascertained and omit it in other cases. ${ }^{20}$

19 William Giles Campbell, Form and Style in Thesis Writing (Boston: Houghton Mifflin, 1954), p. 26.

${ }^{20}$ Charles A. Cutter, Rules for a Dictionary Catalog (4th ed., rewritten; Washington: U.S. Government Printing Office, 1904), p. 102. 
Though he gave as his example an original date of 1545 , the work by Courthope surely would come under this rule. Unfortunately the high standard recommended by Cutter in this matter has not been followed, or even widely advocated, in recent years. The remarks of McKerrow bear out this complaint to some extent, though he was writing mainly about the books of the eighteenth century and earlier.

It may, however, be well to caution young students against blindly accepting the conjectural dates given in the catalogues of libraries. . . Librarians have better opportunities than most people of settling such points correctly, but they are not infallible. ...21

It may be asked whether the reader cannot be expected to see for himself the effective date of a book's ideas after he has examined it or read a little of the text. There are two points to consider. First, if the reader retrieves a book from the stacks on the basis of a publication date given in the catalog, will he be disappointed that the date is, for his purpose, not the real one, and with justice complain about the quality of the cataloging in that library? Second, will the unsophisticated reader recognize from the physical evidence of the book that it is a reprint made from older plates, and avoid a false impression as to the date of the content? This in turn brings up the question of how the cataloger may recognize such a work.

\section{What Can the Cataloger Do?}

This problem is related to one which has long concerned the analytical bibliographer. At one time printers could not afford to leave type standing, so when the available stock of a book was ex-

\footnotetext{
${ }^{21}$ Ronald B. McKerrow, An Introduction to Bibliography for Literary Students (Oxford: at the Clarendon Press, 1927), p. 200.
}

hausted, new type had to be set, and the new "edition" was easily distinguished from the old. But processes such as stereotyping and electroplating in the nineteenth century made the problem of identification much greater. How then is one to ". . . distinguish the reprints of the nineteenth-century American publisher if the latter merely reprinted from plates without so much as a reprint notice?"22 The solution to the problem is not easy, by any means. Blanck suggested, "It is not a question of merely describing what we see; it is rather the problem of interpreting the physical facts of the book." He made reference to Merle Johnson's broken-type theory"a system so revealing and so simple that it must, eventually, be generally accepted."23

Johnson was quite taken with the idea of plate wear and broken type as a way of studying bibliography, perhaps making the method too difficult and also too scientific. "A good practical printer can tell more about first editions than all your experts. He knows the mysteries of make ready, stereotyping, plate making and all that. ..."24 In the preface of his famous American First Editions, Johnson added, "The study of the effect of wear caused by repeated printings from . . . stereotyped or electrotyped plates ... is a scientific study based on physical evidence." 25

Colby gave similar suggestions on how to identify plates used in later printings of books, using as one example Joseph Conrad's Lord Jim. "We conclude, then, that in 1917 the old plates were secured

2 Jacob Blanck, "Problems in the Bibliographical Description of Nineteenth-Century American Books," Papers of the Bibliographic Society of America, XXXVI (second quarter 1942), 128.

2 Ibid., p. 129, 130.

24 Merle Johnson, High Spots of American Literature (New York: Bennett Book Studios, Inc., 1929), p. 109.

${ }^{25}$ Merle Johnson, ed., American First Editions (revised and enlarged ed.; New York: R. R. Bowker, 1932), p. viii. 
from the original publishers and used again."26

A further complication is present in our time, because of the widespread use of plates made from photographic copies of the original. Bruccoli showed some of the difficulties of describing such books, declaring that ". . . a rudimentary knowledge of the use of duplicate plates is requisite for anyone-critic or bibliographer-working with machine printed books." ${ }^{27}$ For the cataloger, it may be well to look for clues in the style of type. Often type composed forty or more years ago will differ enough from present-day styles to cause question. Surely

${ }^{26}$ Elbridge Colby, “A Sample of Bibliographical Method," Papers of the Bibliographic Society of Ameri$c a$, XVI, pt. 2 (1922), p. 126. The broken-type theory obviously has limitations in the study of bibliography, as pointed out, e.g., in Campbell R. Coxe, "The Prepublication Printings of Tarkington's Penrod," Studies in Bibliography, Papers of the Bibliographical Society of the University of Virginia, 1952-1953, 153157; Oliver L. Steele, "Evidence of Plate Damage as Applied to the First Impression of Ellen Glasgow's The Wheel of Life (1906)," Papers . . . , 1963, 223-231.

${ }^{27}$ Matthew J. Bruccoli, "A Mirror for Bibliographers: Duplicate Plates in Modern Printing," Papers of the Bibliographic Society of America, LIV (second quarter $1960), 84$. it is not too much to ask of a professional cataloger that he be enough aware of typography to spot unusual or suspicious examples. Once the question is raised as to the true date of a book's ideas, it is possible to find evidence from the style of writing and expression, or from the dates of literature cited, or even from the content of the book itself. At least the cataloger should become expert enough to know when to seek the advice of a specialist in an effort to ascertain facts about the printing.

The date of ideas, then, is highly important in a library catalog, a bibliography, or any information retrieval system. The rules used to guide catalogers should be strengthened to reflect this importance. Catalogers and information specialists, if they are to serve their patrons-both the common readers and those who trust them for model work in bibliography-may need to learn more about bibliographical method. At least they should be able to spot a book whose imprint date is doubtful. Then a highly expert cataloger should establish the effective date of the writing. 